\title{
TEORIA DA CAUSA MADURA E DUPLO GRAU DE JURISDIÇÃO NO NOVO CÓDIGO DE PROCESSO CIVIL ${ }^{1}$
}

\section{MATURE CAUSE THEORY AND JURISDICTION IN DOUBLE DEGREE IN NEW CIVIL PROCEDURE CODE}

\begin{abstract}
Flávia Moreira Guimarães Pessoa Professora Adjunta da Universidade Federal de Sergipe. Professora do Mestrado em Direito da UFS e UNIT, Juíza do Trabalho (TRT 20a Região). Especialista em Direito Processual pela UFSC. Mestre em Direito, Estado e Cidadania pela UGF. Doutora em Direito Público pela UFBA. Líder do grupo de pesquisa "Hermenêutica Constitucional Concretizadora dos Direitos Fundamentais e Reflexos nas Relações Sociais” da Universidade Federal de Sergipe. Aracaju/SE. flaviampessoa@gmail.com
\end{abstract}

\section{Alex Maia Esmeraldo de Oliveira} Promotor de Justiça do Estado de Sergipe. Mestrando em Direito pela Universidade Federal de Sergipe (UFS). Graduado em Direito pela Universidade Federal da Bahia (UFBA). Membro do grupo de pesquisa "Hermenêutica Constitucional Concretizadora dos Direitos Fundamentais e Reflexos nas Relações Sociais" da Universidade Federal de Sergipe. Aracaju/SE.

RESUMO: O presente escrito se propõe a analisar o art. $515, \S 3^{\circ}$ do Código de Processo Civil a que se convencionou denominar de Teoria da Causa Madura. A mirada será sobre seus contornos atuais sob a ótica da ciência processual e sua posição jurisprudencial, acentuando a dicotomia que se formou entre duas grandes vertentes acerca de seu alcance. Por se tratar de um efeito específico da apelação, serão abordadas

\footnotetext{
${ }^{1}$ Artigo recebido em 07/04/2015 e aprovado em 21/06/2015.
} 
Revista Eletrônica de Direito Processual - REDP. Volume 15. Janeiro a Junho de 2015 Periódico Semestral da Pós-Graduação Stricto Sensu em Direito Processual da UERJ. Patrono: José Carlos Barbosa Moreira. www.redp.com.br ISSN 1982-7636 PP 195-212

suas conexões com o duplo grau de jurisdição, tido como um dos dogmas mais atingidos com essa inovação em nosso sistema. Por sua vez busca-se demonstrar sua funcionalidade atrelada a conferir concretude ao postulado constitucional da duração do razoável do processo. Por derradeiro se debruçara sobre a nova codificação, a qual dá um tratamento revolucionário à teoria.

PALAVRAS-CHAVE: Teoria da Causa Madura. Duplo grau de jurisdição. Duração razoável do processo. Novo Código de Processo Civil.

\begin{abstract}
This writing is to analyze the art. 515, $\S 3$ of the Civil Procedure Code the so-called Theory Mature Cause. The gaze is on your current contours from the perspective of procedural science and its jurisprudence, highlighting the dichotomy that was formed between two main aspects about their scope.. Because it is a specific effect of the appeal, if address their connections with the two levels of jurisdiction, considered one of the hardest hit dogmas with this innovation in our system. In turn seek to demonstrate their functionality linked to concretize the constitutional principle of reasonable duration of the process. For ultimate will look at the new coding, which gives a revolutionary treatment to the theory.
\end{abstract}

KEYWORDS: Theory Mature Cause. Two levels of jurisdiction. Reasonable duration of the process. New Code of Civil Procedure.

\title{
1 INTRODUÇÃO
}

A Teoria da Causa Madura, insculpida no art. 515, $\S 3^{\circ}$ do Código de Processo Civil de 1973, foi introduzida em meio a diversas reformas pontuais sofridas por aquele, atribuindo a um tribunal de apelação o julgamento do mérito quando diante de uma causa apta ao seu enfrentamento, ainda que de forma inédita em relação à instância inferior.

Sob a luz do seu delineamento normativo, foi uma novidade alvissareira, mas que de modo algum deve limitar seu potencial libertador das amarras do tempo à sua literalidade, tendo felizmente sofrido alterações interpretativas ousadas quanto aos seus 
Revista Eletrônica de Direito Processual - REDP. Volume 15. Janeiro a Junho de 2015 Periódico Semestral da Pós-Graduação Stricto Sensu em Direito Processual da UERJ. Patrono: José Carlos Barbosa Moreira. www.redp.com.br ISSN 1982-7636 PP 195-212

limites. Tais alterações foram decisivas como impulso a um perfil proposto pelo novo Código de Processo Civil de 2015.

Nessa linha de abordagem do atual modelo com o vindouro, urge uma filtragem do instituto pela ótica do postulado da duração razoável do processo, consequentemente demonstrando o equívoco doutrinário em torná-la servil a duplo exame obrigatório.

Este instituto veio à lume para conferir maior celeridade às demandas judiciais, mas diante de seu arcabouço inovador provocou críticas, sobretudo porque abalou alguns preceitos consagrados do processo civil. Em particular cogitou-se sua colisão com o duplo grau, tese que iremos refutar dada a sua natureza jurídica de uma autêntica fixação de competência funcional outorgada aos tribunais de apelação para decidirem o mérito com primazia sobre o primeiro grau.

Secundariamente, se divisou possível vulneração aos postulados do contraditório e ampla defesa neste julgamento originário em grau de apelação. A par disto, poderia gerar um prejuízo indesejado ao recorrente, portando ferindo a proibição da reformatio in pejus.

Tais objeções, além de ainda revelar a existência de um processo civil extremamente formalista e apartado de uma preocupação com seu resultado útil, também se distancia de uma exegese que favoreça a efetividade do princípio constitucional da duração razoável do processo.

É de todo censurável a tentativa de confinar um instituto arrojado na busca da tempestividade e eficiência da prestação jurisdicional, posto que sua aplicação adstrita à interpretação gramatical da norma do art. $515, \S 3^{\circ}$ do Estatuto Processual representa um resquício do legalismo tão ao gosto do positivismo jurídico, impedindo uma compreensão mais ampla daquele como instrumento por excelência para otimizar valores constitucionais.

Partindo da mudança de perspectiva com relação a sua natureza jurídica é possível, como já vem fazendo alguns tribunais, aprofundar sua configuração em nome de postulados de status constitucional, mesmo que extrapolando as balizas postas pelo legislador ordinário.

Essa tendência se mostra irreversível a julgar pelo novo código de ritos, o qual se afasta sobremaneira da redação atual - acanhada para os desafios impostos com a crescente judicialização - numa verdadeira guinada em direção a cognoscibilidade do 
Revista Eletrônica de Direito Processual - REDP. Volume 15. Janeiro a Junho de 2015 Periódico Semestral da Pós-Graduação Stricto Sensu em Direito Processual da UERJ. Patrono: José Carlos Barbosa Moreira. www.redp.com.br ISSN 1982-7636 PP 195-212

segundo grau, franqueando-lhe a analise do mérito para questões de fato, a aplicação em caso de sentença definitiva, e passando ao largo da fundamentação recursal, adota este efeito específico em presença de uma postulação seja de reforma ou até mesmo de anulação.

Esse avanço aponta para a gradativa inserção de regras de ordem pública em nosso sistema processual, veiculadoras de interesses comumente albergados na Lei Fundamental, para se contrapor a expedientes condenáveis das partes em postergar a tutela jurisdicional, comportamento este causador de inegáveis prejuízos ao litigante portador do direito violado ou a ser satisfeito bem assim solapa a credibilidade do Poder Judiciário e frustra sua missão de assegurar uma ordem jurídica justa e eficaz.

\section{A TEORIA DA CAUSA MADURA}

Há uma miscelânea de posições quanto a essência da Teoria da Causa Madura, todas orbitando sobre postulados constitucionais e princípios informativos do processo civil que acabam por direcionar o entendimento acerca da sua natureza jurídica.

O efeito que melhor caracteriza o instituto é o translativo.

Como tal considera-se aquele que diz respeito à profundidade da cognição, determinando quais as questões serão transferidas para o tribunal, abarcando tanto as suscitadas (devolutividade) na peça recursal quanto aquelas de ordem pública que são cognoscíveis de ofício, ou seja, mesmo que não tenham sido objeto de impugnação específica.

Esse espectro do efeito translativo se amolda ao instituto em tela porque confere ao órgão recursal o conhecimento de todas as matérias, não necessariamente as de ordem pública, que deveriam ser objeto de uma análise em primeiro grau, permitindo um pronunciamento originário de mérito que envolverá tanto postulações de direito processual quanto de direito material disponível ou indisponível.

Resta evidente que toda as vezes nas quais o sistema autoriza o tribunal a julgar fora do que consta nas razões e contrarrazões recursais está-se diante do efeito translativo, que neste particular se presta a dar concretude ao mencionado princípio da duração razoável do processo.

Como já anunciado predomina a caracterização como efeito translativo da apelação, embora não esteja adstrito a esta modalidade, sendo cabível, em tese, às 
Revista Eletrônica de Direito Processual - REDP. Volume 15. Janeiro a Junho de 2015 Periódico Semestral da Pós-Graduação Stricto Sensu em Direito Processual da UERJ. Patrono: José Carlos Barbosa Moreira. www.redp.com.br ISSN 1982-7636 PP 195-212

demais espécies recursais onde não se mostre vedada a reapreciação de fatos - caso dos recursos extraordinários porque faltaria o prequestionamento - ou que importe a modificação de competência fixada em norma constitucional.

Quanto às hipóteses de cabimento, a primeira corrente (MEDINA, 2013; SOUZA, 2014) acerca desta sistemática prende-se aos ditames da norma no sentido de só admiti-la em presença de questões de direito, onde se debate sobre a vigência, validade e adequada interpretação do texto positivado, e em última instância se houver substrato fático este deve estar imune a controvérsias naquela lide específica.

Prosseguindo com a análise da moldura legal, os estudiosos e notadamente o Superior Tribunal de Justiça ${ }^{2}$ avançaram sobre a sua literalidade, construindo uma exegese acerca do que se entende pela locução "em condições de imediato julgamento" para arrematar que são aquelas com todas as alegações necessárias já feitas e todas as provas admissíveis colhidas.

Deste cenário se observa a existência de duas correntes opostas, uma mais aferrada à letra da norma, restritiva e conservadora, prestigiando a volunta legis e no outro extremo se perfilam os defensores de uma posição mais dilargada sustentando e aplicando a Teoria da Causa Madura a sentenças terminativas que versem não apenas sobre questões de direito como também de fato estando completa a instrução em primeiro grau.

Atualmente há uma clara prevalência doutrinária e jurisprudencial - ad exemplum do Superior Tribunal de Justiça - de uma interpretação mais elástica quanto aos seus requisitos desbordando a mera literalidade do dispositivo.

Neste particular Souza (2014, p. 314 ) foi enfático ao asseverar a consolidação deste posicionamento mais consentâneo com a efetividade e tempestividade da tutela jurisdicional, mesmo demarcando sua posição contrária, pontuando que nossos pretórios se inclinam claramente para admitir uma exegese ampliativa a permitir a incidência do efeito translativo em comento mesmo em matérias a demandar debate sobre fatos.

Compartilha esta posição NERY JÚNIOR (2014, pp. 408-409), seguindo de forma coerente o seu posicionamento segundo o qual a Teoria da Causa Madura é um caso de fixação de competência originária, significando inexistir óbice a que o juízo

\footnotetext{
${ }^{2}$ Neste toar merece destaque os seguintes julgados: STJ, REsp 1179450/MG, 4. ${ }^{\mathrm{a}}$ T., j. 15.05.2012, rel. Min. Luis Felipe Salomão e EREsp 874.507-SC, Rel. Min. Arnaldo Esteves Lima, j.19/06/2013.
} 
Revista Eletrônica de Direito Processual - REDP. Volume 15. Janeiro a Junho de 2015 Periódico Semestral da Pós-Graduação Stricto Sensu em Direito Processual da UERJ. Patrono: José Carlos Barbosa Moreira. www.redp.com.br ISSN 1982-7636 PP 195-212

recursal possa julgar pela primeira vez matéria não apreciada pelo órgão jurisdicional de onde proveio a apelação.

Se pela via recursal pode originariamente conhecer o mérito, então cai por terra a limitação contida no texto do aludido parágrafo terceiro quanto a questões somente de direito, inferindo-se a possibilidade de examinar as matérias de fundo que envolvam acontecimentos, eventos fenomênicos suscetíveis de produção probatória em audiência, exigindo apenas desta seja completa ou desnecessária.

Por completa, compreende-se aquela que franqueou aos litigantes a oportunidade de exercer o contraditório propondo, produzindo e debatendo os fatos através dos meios de convencimento judicial admitidos naquela relação processual, de tal maneira a que se possa afirmar que se permitiu ou houve cabal investigação dos eventos controvertidos.

Reputa-se desnecessária quando os substratos fáticos forem incontroversos, afirmados por uma das partes e confessado pela outra, forem notórios ou mesmo militar em seu favor presunção legal de veracidade e existência consoante preconiza o art. 334 do CPC.

De mais a mais, soa inócua a expressão legislativa "questão exclusivamente de direito" já que, a rigor, toda causa com essa característica, por si mesma, já está em condições de pronto julgamento.

Sob este ângulo da exauriente produção probatória, permitindo o julgamento de questões de fato pelo colegiado recursal e decidindo o mérito com primazia sobre o primeiro grau, torna-se insustentável a oposição a este efeito translativo consistente na suposta ofensa ao contraditório e ampla defesa.

De fato, estes postulados foram escrupulosamente atendidos na instância inferior, porém o juízo sentenciante, apesar da coleta de todos os meios de prova deliberou pela extinção do processo sem examinar o mérito, enfim, a causa estava apta para julgamento, porém aquele se convenceu da existência de uma causa obstativa uma condição da ação ou pressuposto processual - de sua análise emitindo uma sentença terminativa.

Por outro lado igualmente insustentável a possível ofensa ao princípio da proibição da reformatio in pejus, o qual surge ante a possibilidade de o apelante que, ao buscar a nulidade de uma sentença terminativa, veja sua situação processual agravada já que a instância revisora ao analisar o recurso, mesmo dando-lhe provimento e 
Revista Eletrônica de Direito Processual - REDP. Volume 15. Janeiro a Junho de 2015 Periódico Semestral da Pós-Graduação Stricto Sensu em Direito Processual da UERJ. Patrono: José Carlos Barbosa Moreira. www.redp.com.br ISSN 1982-7636 PP 195-212

reconhecendo o error in procedendo, ao avançar sobre os pedidos envolvendo direito material poderá julgar a demanda em seu desfavor, acatando-os ou rejeitando-os conforme o caso.

Primeiro há de sublinhar que a causa madura tem natureza de regra de ordem pública, porquanto como já dito a exaustão converge para o atendimento dos princípios constitucionais da duração razoável do processo e de garantia a uma ordem jurídica justa, de tal maneira a suplantar os interesses privados da parte recorrente, invocando-se no caso em testilha o sistema inquisitivo.

Ademais, a reforma para pior impõe, logicamente, a ocorrência de um pronunciamento judicial adverso ao qual se busca afastar ou minimizar seus efeitos, que na situação em apreço não ocorreu quanto ao enfrentamento do mérito, é dizer, a corte de segundo grau se debruça sobre o bem da vida litigioso de forma inédita, já que a instância inferior por ter proclamado uma preliminar ao mérito deixou de examiná-lo.

Em síntese, não há o que reformar, muito menos para agravar a situação processual do apelante já que o juiz prolator da sentença passou ao largo de decidir o mérito da causa, que sofrerá um veredicto, de forma originária, apenas em segundo grau. Em verdade inexiste revisão visto que ausente uma sentença definitiva, sendo certo que esta se dará em uma primeira oportunidade perante o órgão jurisdicional com competência recursal para a causa.

\section{A atual abordagem do duplo grau de jurisdição e suas implicações sobre a Teoria da Causa Madura}

Sem olvidar a existência de justificativas de ordem jurídica, sociológicas e até psicológica ${ }^{3}$ a defender o seu reconhecimento como um princípio processual, este artigo irá se centrar nos aspectos que mais intimamente se relacionam com a Teoria da Causa Madura.

Como ponto de partida já podemos asseverar a impropriedade da locução pelo prisma da concepção unitária de poder soberano, a sugerir uma pluralidade de

\footnotetext{
${ }^{3}$ Mencione-se a vetusta presunção de maior experiência e, portanto, preparo dos magistrados de segundo grau. Outra justificativa que carece de maior embasamento científico é a afirmação de que o juiz sabedor da revisão de seu pronunciamento por um órgão colegiado então atuaria com mais zelo e proficiência no seu mister.
} 
Revista Eletrônica de Direito Processual - REDP. Volume 15. Janeiro a Junho de 2015 Periódico Semestral da Pós-Graduação Stricto Sensu em Direito Processual da UERJ. Patrono: José Carlos Barbosa Moreira. www.redp.com.br ISSN 1982-7636 PP 195-212 manifestações como se coexistissem diversas instâncias estatais com poder jurisdicional.

Por sua vez vigia uma fortíssima compreensão na literatura (DIDIER JR., 2011, p. 21) de seu status vinculante ao sistema processual a ponto de ser compreendido como duplo grau obrigatório, posição extremada que condicionava o devido processo legal a observá-lo sob pena de se considerar violado (LASPRO, 1995, pp. 94-96).

Tal instituto tem sofrido inúmeras críticas, avultando aquelas que divisam uma profunda desvalorização do primeiro grau, visto que é nele que se operacionalizam a imediatidade na coleta das provas e a oralidade da audiência, elementos fundamentais na formação do convencimento judicial, os quais, via de regra, são ausentes na instância recursal.

MARINONI (2008, p. 500), amparado em doutrina estrangeira, profere duríssimas críticas ao que cognominou de glorificação dos juízos recursais, apontando uma razão histórica para esse tratamento equivocado cuja gênese se assenta numa visão hierárquico-autoritária da jurisdição e do Estado.

Hodiernamente prepondera a compreensão de sua tutela em nome do regime republicano, cuja matriz maior é a imposição da sindicabilidade dos atos estatais, que avulta sua importância em relação ao Poder Judiciário detentor de uma menor representatividade popular, cuja juridicidade de suas manifestações necessita de um controle.Tal aceitação, todavia, não o eleva a posição de princípio de estatura constitucional, por conseguinte de atendimento impositivo.

Laspro (1995, p. 96) lastreando-se em farta literatura estrangeira, notadamente em processualistas italianos, arremata muito bem a questão ao asseverar que a inclusão do duplo grau no Texto Constitucional prende-se a uma deliberação do poder legislativo que irá sopesar, aí sim, outros valores constitucionais a serem forçosamente tutelados porque incorporados ao um rol histórico de garantias fundamentais.

Essa discussão acadêmica não passou despercebida pelo Guardião da Constituição, quem em sucessivas oportunidades ${ }^{4}$, peremptoriamente, afastou a condição de garantia fundamental.

\footnotetext{
4 "No ordenamento jurídico-brasileiro não existe a garantia do duplo grau de jurisdição" (RHC n. 80.919/SP, 2 ${ }^{\mathrm{a}}$ Turma do STF, DJ 14-09-2001). No mesmo diapasão o RE n. 216.257/SP - AgRg, $2^{\mathrm{a}}$ Turma do STF, DJ 11-12-1998: “JURISDIÇÃO. DUPLO GRAU. INEXIGIBILIDADE CONSTITUCIONAL. Diante do disposto no inciso III do artigo 102 da Carta Política da República, no que revela cabível o extraordinário contra decisão de última ou única
} 
Revista Eletrônica de Direito Processual - REDP. Volume 15. Janeiro a Junho de 2015 Periódico Semestral da Pós-Graduação Stricto Sensu em Direito Processual da UERJ. Patrono: José Carlos Barbosa Moreira. www.redp.com.br ISSN 1982-7636 PP 195-212

Em linhas gerais esboçam-se os seguintes fundamentos para lhe negar matriz na Lex Legum. Num primeiro exame porque não se encontra expresso no seu corpo. A previsão de ações penais e cíveis perante do Supremo Tribunal Federal são também claros indicativos de sua não recepção, já que ausente um grau recursal.

No que pertine a invocação ao art. $5^{\circ}, \mathrm{LV}$, da $\mathrm{CF}$ como reconhecimento implícito ao duplo grau, consoante bem apreendido por MARINONI (2008, p. 502) a menção ao vocábulo recurso está semântica e teleologicamente atrelado a consecução da ampla defesa, se a esta inerente, e não que aquele seja indispensável para garanti-la em qualquer situação.

Mesmo em se tratando de uma lide penal, cuja obrigatoriedade residiria na Convenção Interamericana de Direitos Humanos - ao qual o Brasil é signatário e que ingressou em nosso ordenamento em 1992 - cuja previsão no art. 8, no 2, alínea " $h$ " garante ao réu, no processo penal, um segundo julgamento em grau de recurso, o Guardião $^{5}$ da Constituição bem assentou que em se tratando na espécie de garantia constitucional por força da EC 45/04, de nenhuma maneira poderia ostentar uma feição absoluta, sofrendo temperamentos pelo próprio Constituinte.

Nesta linha de intelecção seria mais apropriado mencionar o duplo grau como um princípio informativo do processo civil (SOUZA, p.64).

Como inferência de sua natureza infraconstitucional, por certo quando suscitada sua violação ou posta em discussão a necessidade de observar o duplo grau de modo algum poder-se-ia invocar os métodos hermenêuticos típicos das normas da Lei Fundamental, especialmente os da máxima efetividade e defesa do seu núcleo essencial, muito menos há de se cogitar uma colisão deste com, v.g. o comando constitucional da duração razoável do processo.

A inferência extraída desse panorama é de que a hodierna concepção do duplo grau se harmoniza com a possibilidade de um reexame, apartando-se do elemento obrigatoriedade de uma instância recursal.

Essa perspectiva dá sustentação ao efeito translativo - onde se insere a Teoria da Causa Madura - previsto no art. 515, $\S 3^{\circ}$ do CPC ao tempo em que legitima um aprofundamento das hipóteses de incidência do instituto consoante pretende o novo

instância, o duplo grau de jurisdição, no âmbito da recorribilidade ordinária, não consubstancia garantia constitucional".

${ }^{5}$ No particular veja-se o julgado prolatado no AI n. 601.832/SP -AgRg, $2^{\text {a }}$ Turma do STF, DJ de 3/04/ 2009. 
Revista Eletrônica de Direito Processual - REDP. Volume 15. Janeiro a Junho de 2015

Periódico Semestral da Pós-Graduação Stricto Sensu em Direito Processual da UERJ. Patrono: José Carlos Barbosa Moreira. www.redp.com.br ISSN 1982-7636 PP 195-212

Codex, e como se viu ao longo deste escrito converge para conferir efetividade à duração razoável da demanda, enfim, não guardando relação com o duplo grau aqui entendido como potencial revisão de uma causa por outra esfera ${ }^{6}$ jurisdicional.

É imperioso pontuar que a inserção do duplo grau no debate acerca da aplicabilidade e alcance da causa madura, e por inferência neste breve artigo, decorre da censura feita por parte dos estudiosos em divisar uma possível violação daquele por retirar a revisibilidade do mérito, que por um salto é enfrentado diretamente pela esfera recursal, em geral pelos tribunais de apelação, sem o prévio julgamento pelo juiz singular.

Entretanto, na linha até seguida, ressai de forma inquestionável que o entendimento acerca do duplo grau repousa na ideia de possibilidade de um novo julgamento sobre a lide por outro órgão judicante, caracterizado pelo efeito devolutivo, circunstância diversa da aplicação da causa madura onde o exame do mérito se dará de forma originária por uma instância superior, sem limitações de ordem processual ou ligadas a natureza do direito material em disputa, portanto, intrinsecamente associada a eficácia translativa.

Como bem assentou Nery Junior (2014, pp. 64-65) a apelação de sentença terminativa quando provida pela instância recursal com enfrentamento do mérito, sem que o primeiro grau houvesse decidido sobre este, a rigor, remete a uma discussão sobre a competência do órgão judicante para conhecer e julgar determinada demanda.

Esta situação processual, na interpretação do prestigiado processualista, em nada se relaciona com o duplo grau, reputando equivocado o diagnóstico feito por parcela da doutrina em vislumbrar no efeito translativo da apelação uma supressão de um grau de jurisdição.

Emergem destas colocações que os propósitos colimados pela adoção deste efeito é prestigiar a efetividade processual, a celeridade, conferindo um tratamento condizente à verdadeira dimensão da tutela jurisdicional, que é a de um direito fundamental (art. 5, $\mathrm{XXXV}$ da $\mathrm{CF}$ ), de natureza instrumental voltado à proteção judicial ofertada pelo Estado.

\footnotetext{
${ }^{6} \mathrm{O}$ emprego da palavra foi para demarcar a existência do reexame por outro órgão do Poder Judiciário, não necessariamente por uma instância superior. Preferiu-se seu uso pois desloca a associação do duplo grau a um novo exame por um nível recursal representado por órgão hierarquicamente mais elevado dentro do organograma de cada ramo do Judiciário. Duplo exame de maneira alguma implica dualidade de grau de jurisdição, como bem demonstra a sistemática dos Juizados ao preverem a Turma Recursal composta por Juízes de primeiro grau.
} 


\section{A duração razoável do processo como postulado a ser concretizado pelo efeito translativo do art. 515, $\S 3^{\circ}$ do CPC de 1973}

Nesta quadra se apontará a consonância entre a aplicação desse efeito recursal e a busca por uma resposta estatal efetiva e em tempo hábil a garantir as pretensões de direito material que as partes desejam ver satisfeitas com a intervenção do Poder Judiciário.

Como dito linhas atrás a compreensão de uma dupla revisão compulsória, especialmente em matéria de fato, ad exemplum da Turma Recursal - art. 41, § $1^{\mathrm{o}}$, da Lei 9099/95 - é uma exigência contraproducente face uma sociedade cada vez mais ávida por soluções céleres, permeada por relações e conflitos dinâmicos carentes de uma resolutividade quase imediatista, em um mundo que aboliu as fronteiras e as distâncias para se comunicar, circular riqueza e realizar trocas culturais e sociais instantâneas.

Aqui nos referimos em particular ao grande dilema - e porque não dizer frustração - do processo civil moderno em atalhar os efeitos deletérios do tempo sobre as demandas judiciais, que ficam cada vez mais gritantes neste contexto de um mundo globalizado.

A intolerável lentidão da prestação jurisdicional, dentre outros fatores, se fortalece justamente pela sacralização do duplo grau, ao tempo em que vulnera a efetividade e o mandamento constitucional da duração razoável, constituindo em mais um sério argumento a depor contra seu pretendido status de garantia implícita prevista na Lei Maior.

A imaginada busca pela certeza e aperfeiçoamento da atividade judicial conduz a uma insegurança, pois a definição da causa passa a ser incerta diante do labirinto recursal previsto em nosso sistema, tudo em nome da observância cega ao duplo grau.

A previsão do efeito translativo é um forte instrumento para debelar essa insegurança causada pela delonga na solução dos litígios, conferindo a resolução das questões de direito material, em primeira mão, ao Tribunal que julgaria a demanda em grau de apelo, observados evidentemente os pressupostos para sua análise, notadamente a existência de cabal instrução pelo juízo a quo. 
Revista Eletrônica de Direito Processual - REDP. Volume 15. Janeiro a Junho de 2015 Periódico Semestral da Pós-Graduação Stricto Sensu em Direito Processual da UERJ. Patrono: José Carlos Barbosa Moreira. www.redp.com.br ISSN 1982-7636 PP 195-212

Deve-se ter por superada aquela arcaica convicção do processo civil de que um dos seus principais escopos jurídicos era a solução da lide por meio de uma mera decisão judicial ${ }^{7}$, enfim, na esteira na vetusta lição de Ulpiano $^{8}$ dar a cada um o que é seu, associando a equidade a uma resposta estatal que conferisse o bem da vida ao seu vero titular, deixando num segundo plano quando esta tutela iria ocorrer e qual sua efetividade.

Para o alcance do tão decantado acesso a ordem jurídica justa é insuficiente o princípio da indeclinabilidade da jurisdição (art. $5^{\circ}, \mathrm{XXXV}$ da $\mathrm{CF}$ ), urge seja buscada a sua entrega tempestiva, preservando sua utilidade, que ainda atenda aos propósitos do autor da demanda e lhe proporcione de fato o que assegura a norma de direito material, numa palavra, conjugue a celeridade e a efetividade.

A Lei Federal 9099/95 que criou os Juizados é um marco nessa política. Das alterações do Código de Processo Civil, dentre tantas, podemos mencionar a antecipação dos efeitos da tutela, medidas de execução indireta do art. 461, ampliação dos poderes decisórios do relator nos moldes do art. 557, a improcedência in limine do pedido na hipótese prevista no art. 285-A, todas militando em busca da almejada celeridade.

Neste diapasão também o efeito translativo advindo da Lei no. 10.352/2001, que incluiu o $\S 3^{\circ}$ ao art. 515 do Estatuto Processual Civil, e apesar de anterior à promulgação da EC 45/2004 que inseriu expressamente o princípio da duração razoável do processo, com sua constitucionalização ganhou vulto e graças a ela foi paulatinamente dissipando os questionamentos sobre sua compatibilidade à Lei Fundamental, de tal modo que ficou patente um alargamento dos seus contornos legais em nome da máxima efetividade daquele valor agora entronizado na Carta da República.

A causa madura ou apta a imediato julgamento sobre o bem da vida controvertido, que defina a questão de fundo sobre a qual litigam as partes, inova em favor da celeridade franqueando ao segundo grau se debruçar sobre aquela ante a uma relação processual que teve os seus meios de convencimento esgotados em primeiro grau, mas que foi encerrado neste sem adentrar sobre o mérito.

\footnotetext{
${ }^{7}$ Com estrita observância do devido processo legal e seus consectários mais destacados, a saber, o contraditório e a ampla defesa.

${ }^{8}$ É o conhecidíssimo aforisma jus suum cuique tribuere.
} 
Revista Eletrônica de Direito Processual - REDP. Volume 15. Janeiro a Junho de 2015 Periódico Semestral da Pós-Graduação Stricto Sensu em Direito Processual da UERJ. Patrono: José Carlos Barbosa Moreira. www.redp.com.br ISSN 1982-7636 PP 195-212

Ora, isso prestigia a duração razoável do processo porquanto dita sistemática implantada pela técnica da causa madura além de atender a uma lógica formal evidente, já que o Tribunal desde o início é o juízo natural a examinar todas as matérias processuais e de direito material em nível recursal, também previne sérios prejuízos jurídicos às partes que adviriam da demanda prosseguir pendente de julgamento resolutivo de mérito, afora os custos econômicos com a necessidade de aguardar uma sentença de primeiro grau sobre as questões de fundo para só então ofertar nova apelação.

Igualmente esta dinâmica afasta por completo uma delonga imposta com o retorno do processo ao primeiro grau para se obter uma tutela que já poderia ser proferida em segundo grau de forma mais rápida e quiçá definitiva, enfim, evita-se uma dupla jornada de idas e vindas dos autos a dois graus de jurisdição apenas em nome do cumprimento do doppio grado que acaba afetando sobremaneira uma resposta judicial efetiva e tempestiva.

Isso sem descurar o desprestígio que acomete o Poder Judiciário, que não consegue ofertar uma tutela em prazo razoável, enquanto obrigação constitucional, sofrendo um grave desgaste perante a opinião pública que não compreende a razão da excessiva demora do Estado em solucionar os conflitos.

Para dar prevalência a este axioma constitucional é que se defende não apenas a plena incidência deste efeito específico ${ }^{9}$ da apelação, como também a sua máxima expansão em atenção a duração razoável do processo, intento este que moveu a criação do novo CPC.

Numa palavra, o efeito translativo insculpido no art. $515, \S 3^{\circ}$ do Código de Processo Civil cumpre a tarefa de dar a máxima efetividade ao comando constitucional da duração razoável do processo. Alem disso, atende aos anseios da comunidade jurídica de ver aperfeiçoada atividade jurisdicional que sofre diuturnamente com o fator tempo e, finalmente, dá guarida aos reclamos do cidadão que precisa provocar o Estado para obter o cumprimento coativo de direitos e interesses reconhecidos no ordenamento os quais não podem ser postergados e até esvaziados pela via crucis a que se tornaram os processos no Brasil.

\footnotetext{
9 Entenda-se a expressão como designativa da sistemática da causa madura, já que há outros efeitos próprios da apelação como v.g. o devolutivo e suspensivo. Necessário esclarecer que ao se mencionar "específico" de modo algum indica exclusividade, porquanto ao longo deste trabalho se verá que o $\S 3^{\circ}$ do art. 515 se aplica a todas as demais modalidades recursais, desde que possível ao juízo recursal reapreciar questões de fato.
} 


\section{Uma visão panorâmica da Teoria da Causa Madura na nova codificação}

Antes de adentrarmos nos seus pormenores, no propósito de conferir uma melhor didática, transcrevemos a nova dicção legal ${ }^{10}$ acerca da matéria:

[...] Art. 1013. [..]

$\S 3^{\circ} \mathrm{Se}$ o processo estiver em condições de imediato julgamento, o tribunal deve decidir desde logo o mérito quando:

I - reformar sentença fundada no art. 485;

II - decretar a nulidade de sentença por não ser ela congruente com os limites do pedido ou da causa de pedir;

III - constatar a omissão no exame de um dos pedidos, hipótese em que poderá julgá-lo;

IV - decretar a nulidade de sentença por falta de fundamentação.

§ 4º Quando reformar sentença que reconheça a decadência ou a prescrição, o tribunal, se possível, julgará o mérito, examinando as demais questões, sem determinar o retorno do processo ao juízo de primeiro grau.

O novo modelo normativo traz uma solução mais heterodoxa, arrojada, ampliativa, porque não dizer atrevida em relação a anterior sistemática sobre o tema.

Bastaria a previsão do contido no inciso II para empreender uma revolução no efeito translativo.

Sempre recordando que a pedra de toque de sua aplicação, agora sensivelmente aprofundada, é aferir se os contendores têm mais alegações ou provas a serem produzidas, e estas naturalmente sejam relevantes para influir no convencimento do magistrado.

No novo referencial normativo o seu caput se distancia da fórmula limitadora do atual $^{11}$ regramento ao omitir como condição a este efeito a presença de questões

\footnotetext{
${ }^{10} \mathrm{O}$ novo Código de Processo Civil veio à lume por meio da Lei Federal no. 13.105/2015, sancionada em 16 de março do mesmo ano.
} 
Revista Eletrônica de Direito Processual - REDP. Volume 15. Janeiro a Junho de 2015 Periódico Semestral da Pós-Graduação Stricto Sensu em Direito Processual da UERJ. Patrono: José Carlos Barbosa Moreira. www.redp.com.br ISSN 1982-7636 PP 195-212

"exclusivamente" de direito, com isto criando uma imensa abertura de possibilidades para suscitar sua aplicação.

Infere-se dessa opção legislativa o acatamento da evolução jurisprudencial do instituto que vêm admitindo, p. ex. sua inequívoca incidência diante de matéria fática controvertida.

Afastada a necessidade de maior elucidação sobre os acontecimentos do mundo físico que embasam a demanda, por certo esta se encontra pronta para imediato julgamento, em toda sua extensão, aplicando-se o novel figurino da teoria com maior profundidade, a ponto de prever seu cabimento diante de uma sentença de mérito, v.g. que incorreu em um julgamento citra petita.

Neste ponto, há uma verdadeira guinada na atividade de cognição do segundo grau, avançando sobremaneira sobre todos os aspectos envolvidos na lide, sendo irrelevante que o apelo se insurja contra uma sentença de meritis. Igualmente indiferente se o pedido recursal versa sobre error in procedendo ou error in judicando, de tal modo que mesmo atestando uma ilegalidade da sentença apelada o tribunal poderá prosseguir em seu julgamento, contanto, por evidente, que a causa esteja em condições de julgamento.

Este preceito, é bom que se frise, não guarda equivalência com a omissão na deliberação de algum pedido de meritis, que também é um avanço em relação ao atual arcabouço legal.

Se é consenso a preocupação em maximizar um mandamento constitucional comumente desatendido, que se construa uma regra audaciosa e portadora de uma forte carga eficacial, ao invés da edição de meias-medidas como, lamentavelmente, tem se caracterizado o trabalho do nosso legislador em matéria processual.

De qualquer forma, ressoa nítido o propósito da nova codificação em permitir a aceleração da prestação jurisdicional, evitando que o julgamento do Tribunal se limite a ter caráter meramente rescindente.

${ }^{11}$ Diz-se atual ante a vigência do Código de Processo Civil de 1973 que fica estendida até o fim da vacatio legis da Lei Federal 13105/2015 que ocorrerá em 16 de março de 2016 consoante determina seu art. 1045. 
Revista Eletrônica de Direito Processual - REDP. Volume 15. Janeiro a Junho de 2015 Periódico Semestral da Pós-Graduação Stricto Sensu em Direito Processual da UERJ. Patrono: José Carlos Barbosa Moreira. www.redp.com.br ISSN 1982-7636 PP 195-212

Por derradeiro contemplou-se a sentença que declara a prescrição ou decadência, por ser efetivamente pronunciamento sobre o mérito o novel estatuto optou, com acerto, em positivar o cabimento em atenção a uma prática já consolidada ${ }^{12}$ pelos tribunais.

É preciso fazer uma pequena digressão sobre essas matérias. Havendo a extinção do feito de forma prematura, impedindo uma das partes demonstrar que houve alguma causa de suspensão ou interrupção ou de qualquer modo cerceou a ampla produção probatória hábil a permitir uma cognição judicial plena e exauriente, por ilação estariam comprometidos os mandamentos da ampla defesa e contraditório.

Diante da nova perspectiva legislativa há ampliação dos poderes decisórios dado ao tribunal de apelação, que já era o competente para enfrentar o meritum diante de uma sentença definitiva, nada mais fazendo que abreviar o procedimento, atendendo à efetividade, celeridade e economia processuais.

Todas estas inovações são postas justamente para evitar que o processo siga um percurso inútil, baixando ao primeiro grau e retomando ao segundo, exatamente com o mesmo material cognoscitivo que já está à sua disposição.

Topograficamente a causa madura permaneceu no dispositivo que trata dos efeitos consagrados a apelação, tal como sucede hoje, e deverá seguir a já consolidada exegese que reconhece a essa norma a natureza de cláusula geral em matéria de recursos, por conseguinte abarcando outras modalidades com as ressalvas já mencionadas no tópico 2.2 .

Resta-nos esperar que o elogiável trabalho de nosso Parlamento não vire tabula rasa nas mãos de interesses corporativos - em particular os integrantes dos tribunais de segundo grau - dado o potencial de aumento na carga de trabalho sobre o juízo recursal, assim também deseja-se que a cultura demandista - quanto mais instrumentos de impugnação mais dividendos financeiros aos respectivos profissionais - não oculte os seus interesses mercadológicos sob o véu da pseudodefesa de postulados constitucionais.

\section{Considerações finais}

\footnotetext{
${ }^{12}$ Neste sentido vem decidindo o Superior Tribunal de Justiça, ad instar do que apreciado no Recurso Especial n $n^{\circ} 724 / 710 /$ RJ, rel. Min. Luiz Fux, julgado em 20/11/2007.
} 
Revista Eletrônica de Direito Processual - REDP. Volume 15. Janeiro a Junho de 2015 Periódico Semestral da Pós-Graduação Stricto Sensu em Direito Processual da UERJ. Patrono: José Carlos Barbosa Moreira. www.redp.com.br ISSN 1982-7636 PP 195-212

Restou bem delineado ser legitima e constitucional a aplicação da Teoria da

Causa Madura.Assentando-se no axioma constitucional da duração razoável do processo, o tribunal nada mais estará fazendo que emitir desde logo um pronunciamento sobre o mérito que, depois, será emitido de qualquer modo havendo novo recurso de apelação.

São grandes as vantagens hauridas deste instrumento de aceleração do resultado do processo, já que ao mesmo efeito prático se chegaria - certamente em maior tempo - se o órgão recursal determinasse a baixa dos autos ao juízo de origem para que ali proferisse julgamento sobre o mérito, depois retornando aquele colegiado, se interposta outra apelação, e agora sim emitisse um veredito sobre o objeto do processo.

De outro tanto, restou assentado que a teoria da causa madura é manifestação de uma competência funcional ao órgão ad quem implicando dizer que o tribunal tem o dever de decidir a lide quando ocorrente a hipótese estabelecida no respectivo dispositivo, à revelia da vontade das partes, apesar da cautela procedimental de antes de assim proceder cientificá-las para anterior manifestação.

Para reforçar este efeito em nosso sistema, o novo Código de Processo Civil promoveu sensível modificação do instituto, estendendo-o a situações em que se insurge contra sentença meritória, em presença de fundamentos recursais de anulação ou reforma, incongruência com a causa de pedir, enfim, novas hipóteses de incidência em franco alinhamento com a tempestividade e efetividade a tutela jurisdicional.

Urge a adoção plena desta teoria, sem as reservas apontadas ao longo deste artigo, caso se pretenda levar a sério enfrentar a crônica morosidade que atinge nossa Justiça.

De pouca valia são as medidas administrativas e planos estratégicos voltados a acelerar os processos, de que é exemplo emblemático as metas fixadas pelo Conselho Nacional de Justiça (CNJ), sem a devida outorga aos juízes de ferramentas jurisdicionais eficazes para cumpri-las.

Neste cenário, o novo Código de Processo Civil é um alento, municiando, dentre outros recursos técnicos, o Poder Judiciário com o aprofundamento da Teoria da Causa Madura para reverter a batalha contra os males do tempo.

\section{REFERÊNCIAS BIBLIOGRÁFICAS}


Revista Eletrônica de Direito Processual - REDP. Volume 15. Janeiro a Junho de 2015

Periódico Semestral da Pós-Graduação Stricto Sensu em Direito Processual da UERJ.

Patrono: José Carlos Barbosa Moreira. www.redp.com.br ISSN 1982-7636 PP 195-212

BARIONI, Rodrigo. “A proibição da reformatio in pejus e o $\S 3 .^{\circ}$ do art. 515 do CPC”. In: NERY JUNIOR, Nelson; WAMBIER, Teresa Arruda Alvim (Coord.). Aspectos polêmicos e atuais dos Recursos Cíveis e de outros meios de impugnação às decisões judiciais. São Paulo: Revista dos Tribunais, 2005.

BRASIL, STF, $2^{\text {a }}$ Turma, RHC n. 80.919/SP, DJ 14-09-2001. , $2^{\text {a }}$ Turma, AI n. 601.832/SP -AgRg, DJ de 3/04/ 2009.

BRASIL, STJ, 4. ${ }^{\text {a }}$ Turma, AgRgAg 867885-MG, rel. Min. Hélio Quaglia Barbosa, DJ 22.10.07. , REsp n. 756.844/SC.

BUENO, Cássio Scarpinella. Curso Sistematizado de Processo Civil: Recursos, Processos e Incidentes nos Tribunais. Sucedâneos Recursais: técnicas de controle das decisões judiciais. $5^{\mathrm{a}}$ edição. São Paulo: Saraiva, 2014, v. 5.

DIDIER JR., Fredie; ZANETI JR., Hermes. Curso de Direito Processual Civil: Meios de Impugnação às decisões judiciais e processo nos Tribunais. $9^{\mathrm{a}}$ ed. Salvador: Editora JusPodium, 2011, v. 3.

LASPRO, Oreste Nestor de Souza. Duplo Grau de Jurisdição no Direito Processual Civil. São Paulo: Revista dos Tribunais, 1995.

MARINONI, Luiz Guilherme; ARENHART, Sérgio Cruz. Processo de Conhecimento. $7^{\mathrm{a}}$ edição, $2^{\mathrm{a}}$ tiragem. São Paulo: Revista dos Tribunais, 2008, v. 2.

MEDINA, José Miguel Garcia; WAMBIER, Teresa Arruda Alvim. Processo Civil Moderno: Recursos e Ações Autônomas de Impugnação. $3^{\mathrm{a}}$ edição. São Paulo: Revista dos Tribunais, 2013, v. 2.

MOREIRA, José Carlos Barbosa. Comentários ao Código de Processo Cívil. 11 ${ }^{\mathrm{a}}$ edição. Rio de Janeiro: Forense, 2003, v. 5.

NERY JÚNIOR, Nelson. Teoria Geral dos Recursos. $7^{\mathrm{a}}$ edição.São Paulo: Revista dos Tribunais, 2014.

PESSOA, Flávia Moreira Pessoa (Org.). Constituição e Processo. Aracaju: Evocati, 2014.

SOUZA, Bernardo Pimentel. Introdução aos Recursos Cíveis e à Ação Rescisória. $10^{\mathrm{a}}$ edição. São Paulo: Saraiva, 2014. 